\title{
Asymmetric Synthesis of Axinellamines A and B
}

\author{
Dr. Zhiqiang Ma, Dr. Xiao Wang, Dr. Yuyong Ma, and Prof. Dr. Chuo Chen* \\ Department of Biochemistry, The University of Texas Southwestern Medical Center, 5323 Harry \\ Hines Boulevard, Dallas, TX 75390 (USA)
}

\begin{abstract}
Axinellamines A and B are broad-spectrum anti-bacterial pyrrole-imidazole alkaloids that have a complex polycyclic skeleton. A new asymmetric synthesis of these marine sponge metabolites is described herein, featuring an oxidative rearrangement and an anchimeric chlorination reaction.
\end{abstract}

\section{Keywords}

alkaloids; anchimeric assistance; axinellamines; natural products; total synthesis

\begin{abstract}
Axinellamines (1) are members of a family of dimeric pyrrole-imidazole natural products that have attracted the attention of synthetic chemists for decades (Figure 1). ${ }^{[1]}$ Initially isolated by Quinn et al., ${ }^{[2]}$ these marine alkaloids have a densely functionalized polycyclic structure highly rich in nitrogen and halogen atoms ( $\mathrm{C}: \mathrm{N}: \mathrm{X} \approx 4: 2: 1)$. Recently, Romesberg, Baran, and co-workers have found that $\mathbf{1 a}$ and $\mathbf{1 b}$ display promising activity against both Gram-positive and Gram-negative bacteria and 1a causes membrane destabilization in Escherichia coli. ${ }^{[3]}$ Among several labs that study the synthesis of dimeric pyrroleimidazole alkaloids 1-3, ${ }^{[3-16]}$ Carreira et al. reported the first synthetic strategy directed towards $\mathbf{1}^{[6]}$ using a Diels-Alder reaction to establish its fully functionalized cyclopentyl core. Romo and co-workers subsequently disclosed an oxidative ring-contraction approach that was inspired by Scheuer's biosynthetic hypothesis. ${ }^{[7,17]}$ This skeletal rearrangement reaction has also been studied by Lovely et al. ${ }^{[8]}$ The total synthesis of $\mathbf{1}$ was accomplished by the Baran group by using two different approaches. ${ }^{[3-5]}$ The group first used an intramolecular aldol reaction to construct the cyclopentyl core of $\mathbf{1}$. This approach has enabled the asymmetric synthesis of not only $\mathbf{1},{ }^{[4]}$ but also massadines $(\mathbf{2}),{ }^{[9]}$ and palau'amine (3). ${ }^{[10]}$ They subsequently developed a second-generation synthesis wherein the cyclopentyl core of $\mathbf{1}$ was assembled by a Pauson-Khand reaction. ${ }^{[3,5]}$ This new approach has further allowed for the gramscale synthesis of $\mathbf{1}$. Meanwhile, Harran et al. have achieved the synthesis of 13-dechloro-6', $6^{\prime \prime}$-didebromo-1 using an oxidative enolate coupling
\end{abstract}

\footnotetext{
*Chuo.Chen@UTSouthwestern.edu.

Current address: Dr. X. Wang, Dr. Y. Ma, Department of Chemistry and Biochemistry, The University of California, San Diego, 9500 Gilman Drive, La Jolla, CA 92093 (USA)

Dedicated to Professor Stuart L. Schreiber on the occasion of his 60th birthday

Supporting information and the ORCID identification number(s) for the author(s) of this article can be found under http://dx.doi.org/ 10.1002/anie.201600007.
} 
strategy, ${ }^{[11]}$ and Namba, Tanino, and co-workers have reported the synthesis of $\mathbf{3}^{\left[{ }^{[12]}\right.} \mathrm{We}$ report herein a new asymmetric synthesis of $\mathbf{1}$.

Our general synthetic strategy for 1-3 resembles the approach of Romo et al. with a "Scheuer rearrangement" serving as the key transformation. ${ }^{[7,8,14-17]}$ Previously, we used the 10'-hydroxy group of $\mathbf{4}$ (protected ent-10'-hydroxydibromoageliferin) to set up the desired spiro-configuration of $\mathbf{2 a}$ through directed oxidation. ${ }^{[15]}$ However, we were not able to convert this hydroxy directing group into a chloride at a late stage to achieve the synthesis of $\mathbf{1}$. We thus switched to developing a new route with an early introduction of the chloride despite its reported hydrolytic instability. $[5,9,10,18,19]$

Using azidoimidazole 5 (prepared in 10 steps from $(S)$-Garner's aldehyde) $)^{[14,15]}$ as the common intermediate for $\mathbf{1}$ and $\mathbf{2 a}$, the synthesis of axinellamines (1) commenced with the selective reduction of the azido group on the imidazole ring and epimerization of the $\mathrm{C} 12$ stereocenter (Scheme 1). We found that the imidazoyl azide of $\mathbf{5}$ could be reduced immediately upon addition of triphenylphosphine at room temperature, whereas the alkyl azide would not react until warming the reaction mixture to $40^{\circ} \mathrm{C}$. The resulting imidazoyl iminophosphorane is hydrolytically stable over a range of $\mathrm{pH}$ values, making it a good protected form of aminoimidazole. ${ }^{[14 \mathrm{c}]}$ Epimerization of the $\mathrm{C} 12$ stereocenter was achieved after converting the acetonide group into the bulky silyl protecting group TBS (tertbutyldimethylsilyl). In contrast to 5 that strongly favors a cis-11,12-configuration, ${ }^{[14 b]} 12$ epi-6 slowly epimerized under basic conditions to provide a 3:2 mixture of 6 and 12-epi-6 (82\% combined yield over four steps).

To establish the central cyclopentyl ring of $\mathbf{1}$, the ketone group of $\mathbf{6}$ was first reduced to create a directing group for the Scheuer rearrangement. Substituting the previously used lithium triethylborohydride ${ }^{[15]}$ with lithium aluminum hydride eliminated issues associated with the formation of a borane complex of $\mathbf{7}$. Treatment of $\mathbf{7}$ with titanium tetraisopropoxide and tert-butyl hydroperoxide (TBHP) induced the Scheuer rearrangement to afford axinellamine core $\mathbf{8}$ with the desired spiro-configuration. ${ }^{[15]}$

We next set out to develop a method for introducing the C13-positioned chlorine atom. Romo et al. reported that stereoretentive displacement of the $\mathrm{C} 13$ chloride could be achieved by anchimeric assistance of the neighboring nitrogen atom and proposed that massadine (2a) was produced by hydrolysis of the then elusive massadine chloride (2b). ${ }^{[7 \mathrm{~d}]}$ Meanwhile, Köck, Baran, and co-workers successfully isolated $\mathbf{2 b}$ from pyrrole-imidazole alkaloidproducing sponges and demonstrated that $\mathbf{2 b}$ could be hydrolyzed to $\mathbf{2 a}{ }^{[18]}$ The Köck group has further delineated the antiparallel alignment of the leaving group with the neighboring nitrogen atom as a requirement for facile displacement. However, Capon et al. reported that 14- $O$-sulfate massadine (2c) does not hydrolyze to $2 \mathbf{a}$ over a range of $\mathrm{pH}$ values. ${ }^{[19]}$ Thus, proper alignment is not sufficient for anchimeric displacement and there is no direct relationship between the hydrolysis rate and the $\mathrm{p} K_{\mathrm{a}}$ value of the leaving group. ${ }^{[20]}$

We envisioned that chlorination of $\mathbf{8}$ would be a viable approach for the synthesis of $\mathbf{1}$ according to the principle of microscopic reversibility. Indeed, Namba, Tanino, et al. have recently succeeded in using this strategy to synthesize $3 .{ }^{[12]}$ We found that reaction of $\mathbf{8}$ with 
mesyl chloride $(\mathrm{MsCl})$ gave a mesylate that smoothly reacted with tetrabutylammonium chloride to give $\mathbf{1 0}$ through phosphonium aziridine $\mathbf{9}$ (72\% yield over four steps).

To install the dibromopyrrole and aminoimidazole groups, we reduced the azido group of $\mathbf{1 0}$ and selectively removed the less hindered carbamate protecting group using trifluoroacetic acid (TFA) to generate diamine 11. The dibromopyr-role groups were then introduced and the silyl protecting group removed using tetrabutylammonium fluoride (TBAF) to provide alcohol 12 (30\% yield over four steps). The construction of the second aminoimidazole group started with oxidation of the hydroxy group and removal of the carbamate group to give a metastable amino aldehyde that presumably existed as a hydrate according to LCMS analyses. Subsequent condensation with cyanamide ${ }^{[9,10,21]}$ afforded the desired aminoimidazole 13 ( $42 \%$ yield over four steps). The cyclization step could be accelerated by treating the initial condensation product with trifluoroacetic acid. In contrast to Baran's system, ${ }^{[5]}$ our iminohydantoin-bearing chlorides are relatively stable. Hydrolysis only occurred partially with $\mathbf{1 3}$ when carrying out the condensation at elevated temperatures and with extended reaction times. Additionally, there is no epimerization of the C14-spiroquaternary center, as was observed by Harran and co-workers. ${ }^{[22]}$

To complete the synthesis of $\mathbf{1}$, we first adjusted the C1-oxidation state of $\mathbf{1 3}$. During the synthesis of $\mathbf{2 a}$, we found that the C13-hydroxy analogue of $\mathbf{1 3}$ could be reduced easily under a variety of conditions. ${ }^{[15]}$ However, similar treatment of $\mathbf{1 3}$ with calcium borohydride or lithium aluminum hydride resulted in complete decomposition. Attempts to reduce $\mathbf{1 3}$ with sodium borohydride in methanol ${ }^{[13 a]}$ at elevated temperatures led to the formation of methoxide 14. We suspected that, in the synthesis of 2a, the C13-hydroxy group formed a complex with the reducing agent and facilitated $\mathrm{C} 1$ reduction. Therefore, a more nucleophilic hydride is needed to reduce the iminohydantoin group of 13. Indeed, lithium triethylborohydride effectively reduced the C1-carbonyl group of $\mathbf{1 3}$, however, with C13 dechlorination to give $\mathbf{1 5}$.

Eventually, we found that $\mathrm{C} 1$ reduction could be accomplished without dechlorination by treating 13 with samarium diiodide ${ }^{[11]}$ to give aminal 16 with concomitant $6^{\prime}, 6^{\prime \prime}$-didebromination and hydrolysis of the iminophosphorane group. Subsequent oxidation of the aminoimidazole group with AD-mix-a established the N4-C5 linkage and provided the complete axinellamine $\mathbf{B}$ skeleton (d.r. > 10:1). Notably, the oxidative cyclization induced by dioxirane ${ }^{[4]}$ or oxaziridine ${ }^{[11]}$ favors the formation of the alternative axinellamine $\mathrm{A}$ stereochemistry.

Although the synthesis of $\mathbf{1 b}$ was achieved by bromination and deprotection of $\mathbf{1 7}$ initially, we were not able to obtain a consistent yield of $\mathbf{1 6}$ as a result of multiple competing reactions. We thus altered the reaction sequence to establish a robust synthetic route. Treatment of $\mathbf{1 3}$ with boron trichloride gave a mixture of hydroxymethyl and chloromethyl iminohydantoins that could be hydrolyzed together with the iminophosphorane group (52\% yield over two steps). The following oxidative cyclization provided the axinellamine skeletons (55\% yield), however, with diminished stereochemical preference (d.r. = 2:1-3:1). Both AD-mix- $\alpha$ and AD-mix- $\beta$ gave the same diastereoselectivity. Subsequent $\mathrm{C} 1$ reduction proceeded smoothly (67\% yield) to give $\mathbf{1 b}$ from the major diastereomer after reinstallation 
of the $6^{\prime}$ and $6^{\prime \prime}$-bromine atoms (53\% yield). Reduction of the minor diastereomer followed by bromination provided 1a. The CD spectra of our synthetic $\mathbf{1}$ match those of the natural products. ${ }^{[4 \mathrm{c}, 19]}$

In summary, the asymmetric synthesis of axinellamines A and B (1) was achieved in 31 steps from $(S)$-Garner's aldehyde ( $0.01 \%$ and $0.04 \%$ overall yield, respectively). The core structure of 1 was established by directed Scheuer rearrangement and the hydroxy directing group was converted into chloride by anchimeric displacement. Although literature reports suggest that the reverse reaction, namely, the hydrolysis of chloride, is highly favored, we found that the hydrolytic stability of the chloride could be improved by modulating the electronic properties of the adjacent spiro-heterocycle. Application of this approach to the synthesis of other chlorine-containing pyrrole-imidazole dimers is underway.

\section{Supplementary Material}

Refer to Web version on PubMed Central for supplementary material.

\section{Acknowledgements}

We thank the NIH (NIGMS R01-GM079554), the Welch Foundation (I-1868), and UT Southwestern for financial support.

\section{References}

[1]. a) Ma Y, De S, Chen C. Tetrahedron. 2014; 70:1145-1173.b) Wang X, Ma Z, Wang X, De S, Ma Y, Chen C. Chem. Commun. 2014; 50:8628-8639.c) Al-Mourabit A, Zancanella MA, Tilvi S, Romo D. Nat. Prod. Rep. 2011; 28:1229-1260. [PubMed: 21556392] d) Heasley B. Eur. J. Org. Chem. 2009:1477-1489.e) Forte B, Malgesini B, Piutti C, Quartieri F, Scolaro A, Papeo G. Mar. Drugs. 2009; 7:705-753. [PubMed: 20098608] f) Arndt H-D, Riedrich M. Angew. Chem. Int. Ed. 2008; 47:4785-4788.Angew. Chem. 2008; 120:4864-4867.g) Weinreb SM. Nat. Prod. Rep. 2007; 24:931-948. [PubMed: 17898890] h) Köck M, Grube A, Seiple IB, Baran PS. Angew. Chem. Int. Ed. 2007; 46:6586-6594.Angew. Chem. 2007; 119:6706-6714.i) Du H, He Y, Sivappa R, Lovely CJ. Synlett. 2006:965-992.j) Jacquot DEN, Lindel T. Curr. Org. Chem. 2005; 9:1551-1565.k) Hoffmann H, Lindel T. Synthesis. 2003:1753-1783.

[2]. a) Urban S, de Almeida Leone P, Carroll AR, Fechner GA, Smith J, Hooper JNA, Quinn RJ. J. Org. Chem. 1999; 64:731-735. [PubMed: 11674140] b) Yasuda T, Araki A, Kubota T, Ito J, Mikami Y, Fromont J, Kobayashi JI. J. Nat. Prod. 2009; 72:488-491. [PubMed: 19209898]

[3]. Rodriguez RA, Steed DB, Kawamata Y, Su S, Smith PA, Steed TC, Romesberg FE, Baran PS. J. Am. Chem. Soc. 2014; 136:15403-15413. [PubMed: 25328977]

[4]. a) Yamaguchi J, Seiple IB, Young IS, O'Malley DP, Maue M, Baran PS. Angew. Chem. Int. Ed. 2008; 47:3578-3580.Angew. Chem. 2008; 120:3634-3636.b) OÏMalley DP, Yamaguchi J, Young IS, Seiple IB, Baran PS. Angew. Chem. Int. Ed. 2008; 47:3581-3583.Angew. Chem. 2008; 120:3637-3639.c) Seiple IB, Su S, Young IS, Nakamura A, Yamaguchi J, Jørgensen L, Rodriguez RA, O’Malley DP, Gaich T, Köck M, Baran PS. J. Am. Chem. Soc. 2011; 133:1471014726. [PubMed: 21861522]

[5]. Su S, Rodriguez RA, Baran PS. J. Am. Chem. Soc. 2011; 133:13922-13925. [PubMed: 21846138]

[6]. a) Starr JT, Koch G, Carreira EM. J. Am. Chem. Soc. 2000; 122:8793-8794.b) Breder A, Chinigo GM, Waltman AW, Carreira EM. Angew. Chem. Int. Ed. 2008; 47:8514-8517.Angew. Chem. 2008; 120:8642-8645.c) Chinigo GM, Breder A, Carreira EM. Org. Lett. 2011; 13:78-81. [PubMed: 21138327] d) Breder A, Chinigo GM, Waltman AW, Carreira EM. Chem. Eur. J. 2011; 17:12405-12416. [PubMed: 21932242]

Angew Chem Int Ed Engl. Author manuscript; available in PMC 2017 April 04. 
[7]. a) Dilley AS, Romo D. Org. Lett. 2001; 3:1535-1538. [PubMed: 11388860] b) Dransfield PJ, Wang S, Dilley A, Romo D. Org. Lett. 2005; 7:1679-1682. [PubMed: 15844879] c) Dransfield PJ, Dilley AS, Wang S, Romo D. Tetrahedron. 2006; 62:5223-5247.d) Wang S, Dilley AS, Poullennec KG, Romo D. Tetrahedron. 2006; 62:7155-7161.e) Zancanella MA, Romo D. Org. Lett. 2008; 10:3685-3688. [PubMed: 18693745]

[8]. a) Lovely CJ, Du H, He Y, Dias HVR. Org. Lett. 2004; 6:735-738. [PubMed: 14986962] b) Sivappa R, Hernandez NM, He Y, Lovely CJ. Org. Lett. 2007; 9:3861-3864. [PubMed: 17803309]

[9]. Su S, Seiple IB, Young IS, Baran PS. J. Am. Chem. Soc. 2008; 130:16490-16491. [PubMed: 19049446]

[10]. Seiple IB, Su S, Young IS, Lewis CA, Yamaguchi J, Baran PS. Angew. Chem. Int. Ed. 2010; 49:1095-1098.Angew. Chem. 2010; 122:1113-1116.

[11]. Ding H, Roberts AG, Harran PG. Angew. Chem. Int. Ed. 2012; 51:4340-4343.Angew. Chem. 2012; $124: 4416-4419$.

[12]. Namba K, Takeuchi K, Kaihara Y, Oda M, Nakayama A, Nakayama A, Yoshida M, Tanino K. Nat. Commun. 2015; 6:8731. [PubMed: 26530707]

[13]. a) Lanman BA, Overman LE, Paulini R, White NS. J. Am. Chem. Soc. 2007; 129:12896-12900. [PubMed: 17902668] b) Koenig SG, Miller SM, Leonard KA, Löwe RS, Chen BC, Austin DJ. Org. Lett. 2003; 5:2203-2206. [PubMed: 12816409] c) Hudon J, Cernak TA, Ashenhurst JA, Gleason JL. Angew. Chem. Int. Ed. 2008; 47:8885-8888.Angew. Chem. 2008; 120:9017-9020.d) Bultman MS, Ma J, Gin DY. Angew. Chem. Int. Ed. 2008; 47:6821-6824.Angew. Chem. 2008; 120:6927-6930.e) Namba K, Inai M, Sundermeier U, Greshock TJ, Williams RM. Tetrahedron Lett. 2010; 51:6557-6559. [PubMed: 21286237] f) Feldman KS, Nuriye AY, Li J. J. Org. Chem. 2011; 76:5042-5060. [PubMed: 21574600] g) Fukahori Y, Takayama Y, Imaoka T, Iwamoto O, Nagasawa K. Chem. Asian J. 2012; 7:244-250. [PubMed: 23081863] h) Sun C, Lee H, Lee D. Org. Lett. 2015; 17:5348-5351. [PubMed: 26501869]

[14]. a) Tan X, Chen C. Angew. Chem. Int. Ed. 2006; 45:4345-4348.Angew. Chem. 2006; 118:44514454.b) Wang X, Ma Z, Lu J, Tan X, Chen C. J. Am. Chem. Soc. 2011; 133:15350-15353. [PubMed: 21888421] c) Wang X, Wang X-L, Tan X, Lu J, Cormier KW, Ma Z, Chen C. J. Am. Chem. Soc. 2012; 134:18834-18842. [PubMed: 23072663]

[15]. Ma Z, Wang X-L, Wang X, Rodriguez RA, Moore CE, Gao S, Tan X, Ma Y, Rheingold AL, Baran PS, Chen C. Science. 2014; 346:219-224. [PubMed: 25301624]

[16]. O’Malley DP, Li K, Maue M, Zografos AL, Baran PS. J. Am. Chem. Soc. 2007; 129:4762-4775. [PubMed: 17375928]

[17]. a) Kinnel RB, Gehrken H-P, Swali R, Skoropowski G, Scheuer PJ. J. Org. Chem. 1998; 63:32813286.b) Ma Z, Lu J, Wang X, Chen C. Chem. Commun. 2011; 47:427-429.

[18]. a) Grube A, Immel S, Baran PS, Köck M. Angew. Chem. Int. Ed. 2007; 46:6721-6724.Angew. Chem. 2007; 119:6842-6845.b) Grube A, Immel S, Baran PS, Köck M. Angew. Chem. Int. Ed. 2007; 46:8107-8107.Angew. Chem. 2007; 119:8253-8253.

[19]. Zhang H, Khalil Z, Conte MM, Plisson F, Capon RJ. Tetrahedron Lett. 2012; 53:3784-3787.

[20]. a) Stirling CJM. Acc. Chem. Res. 1979; 12:198-203.b) Boyd DB. J. Org. Chem. 1985; 50:885886.c) Pearson RG. J. Org. Chem. 1987; 52:2131-2136.d) Anderson JSM, Liu Y, Thomson JW, Ayers PW. J. Mol. Struct. Theochem. 2010; 943:168-177.

[21]. Foley LH, Büchi G. J. Am. Chem. Soc. 1982; 104:1776-1777.

[22]. Ding H, Roberts AG, Harran PG. Chem. Sci. 2012; 3:303-306.

Angew Chem Int Ed Engl. Author manuscript; available in PMC 2017 April 04. 


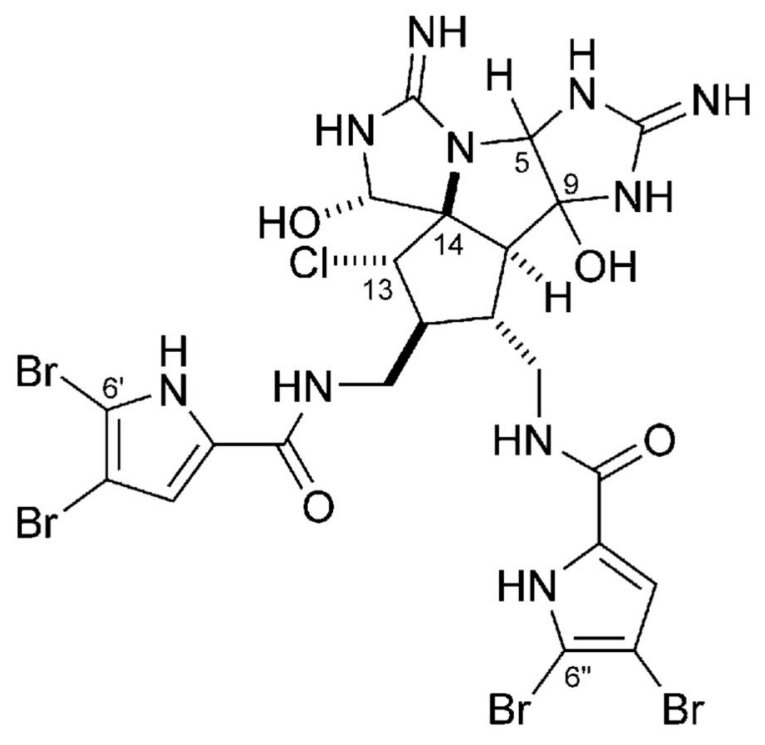

Axinellamine $\mathrm{A}(1 \mathrm{a}): 5-\mathrm{H}, 9-\mathrm{OH}=\beta$

Axinellamine $\mathrm{B}(\mathbf{1 b}): 5-\mathrm{H}, 9-\mathrm{OH}=\alpha$

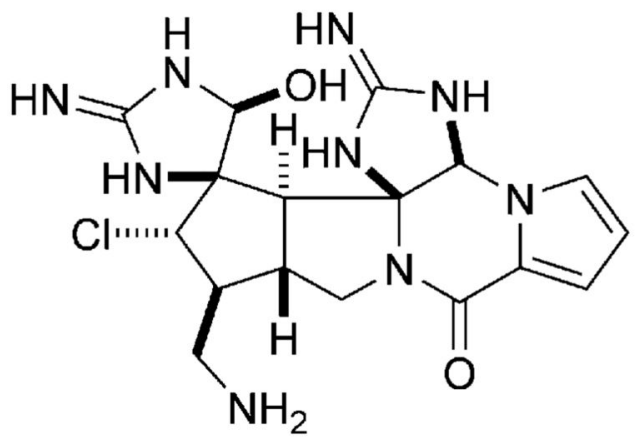

Palau'amine (3)

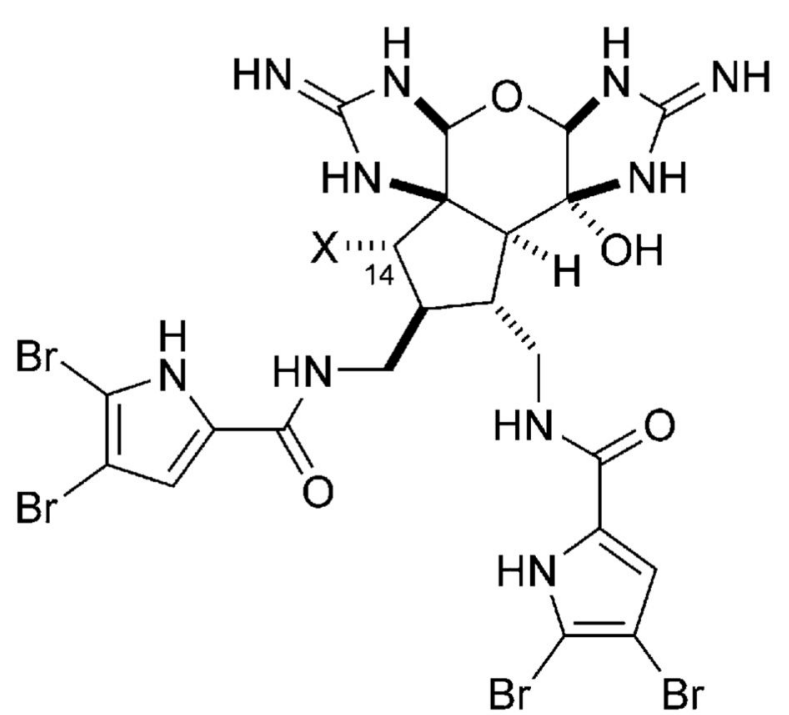

Massadine (2a): $\mathrm{X}=\mathrm{OH}$ Massadine chloride (2b): $X=\mathrm{Cl}$ 14-O-Sulfate massadine (2c): $\mathrm{X}=\mathrm{OSO}_{3}{ }^{-}$<smiles>N=c1[nH]cc([C@@H]2c3nc(N=[Pb])n(OC(=O)c4ccccc4)c3[C@@H](O)[C@@H](CNC(=O)c3cc(Br)c(Br)[nH]3)[C@@H]2CNC(=O)c2cc(Br)c(Br)[nH]2)[nH]1</smiles>

Figure 1.

The structures of axinellamines (1), massadines (2), palau' amine (3), and protected ent-10'hydroxydibromoageliferin (4). 

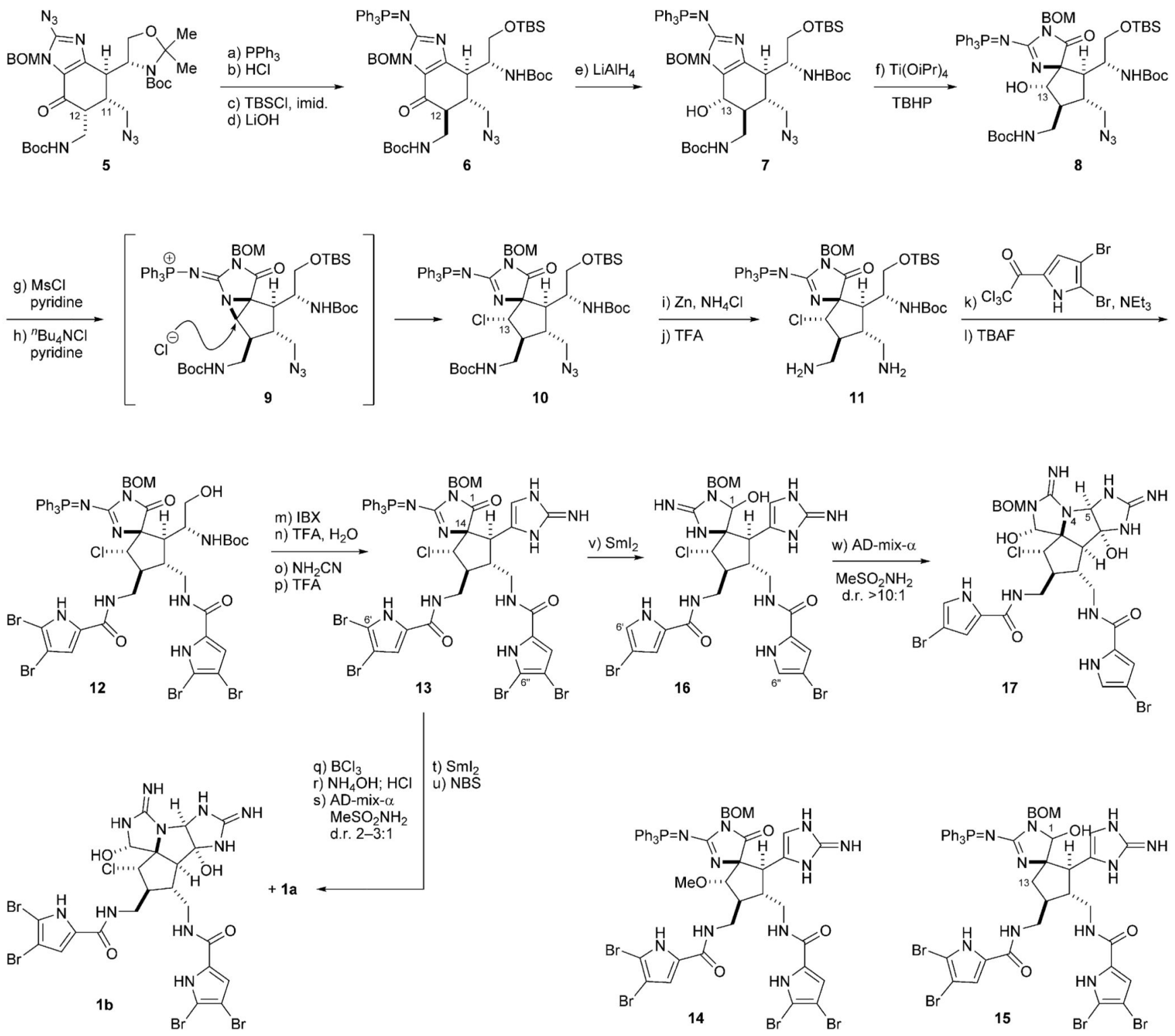

Scheme 1.

Synthesis of axinellamines. Reaction conditions: 5 $\rightarrow$ 6: a) $\mathrm{PPh}_{3}, \mathrm{THF}, 23^{\circ} \mathrm{C}, 2 \mathrm{~h}$; b) $\mathrm{HCl}$, EtOAc, $23^{\circ} \mathrm{C}, 2 \mathrm{~h}$; c) TBSCl, imidazole, $\mathrm{CH}_{2} \mathrm{Cl}_{2}, 23^{\circ} \mathrm{C}, 2 \mathrm{~h}$; d) $\mathrm{LiOH}, \mathrm{THF} / \mathrm{H}_{2} \mathrm{O}$ 4/1 v/v, $23^{\circ} \mathrm{C}, 48 \mathrm{~h}\left(49 \% 6\right.$ and $33 \%$ 12-epi-6 over 4 steps). 6 $\rightarrow$ 7: e) $\mathrm{LiAlH}_{4}$, THF, $0^{\circ} \mathrm{C}, 1$ h. 7 $\rightarrow \mathbf{8 :}$ f) $\mathrm{Ti}\left(\mathrm{O}^{\mathrm{i} P r}\right)_{4}$, TBHP, $4 \AA$ 品olecular sieves, $\mathrm{CH}_{2} \mathrm{Cl}_{2} /$ decane $190 / 1 \mathrm{v} / \mathrm{v},-20 \rightarrow 0^{\circ} \mathrm{C}, 2$ h. 8 $\left.\rightarrow \mathbf{1 0}: \mathrm{g}\right)$ $\mathrm{MsCl}$, pyridine, THF, $\left.0 \rightarrow 23^{\circ} \mathrm{C}, 1 \mathrm{~h} ; \mathrm{h}\right){ }^{n} \mathrm{Bu}_{4} \mathrm{NCl}, 4 \AA$ molecular sieves, pyridine, $70^{\circ} \mathrm{C}, 12 \mathrm{~h}$ $\left(72 \%\right.$ over 4 steps (from $6 \rightarrow \mathbf{1 0}$ )). 10 $\rightarrow \mathbf{1 2}$ : i) $\mathrm{Zn}, \mathrm{NH}_{4} \mathrm{Cl}, \mathrm{MeOH} / \mathrm{H}_{2} \mathrm{O} 10 / 1 \mathrm{v} / \mathrm{v}, 23^{\circ} \mathrm{C}, 3 \mathrm{~h} ; \mathrm{j}$ ) TFA, $\mathrm{CH}_{2} \mathrm{Cl}_{2}, 23^{\circ} \mathrm{C}, 80 \mathrm{~min}$; k) 4,5-dibromo-2-(trichloroacetyl)pyrrole, $\mathrm{NEt}_{3}, \mathrm{DMF}, 50^{\circ} \mathrm{C}$, $12 \mathrm{~h}$; 1) TBAF, THF, $23^{\circ} \mathrm{C}, 48 \mathrm{~h}(30 \%$ over 4 steps). 12 $\rightarrow 13: \mathrm{m})$ IBX, DMSO, $40^{\circ} \mathrm{C}, 15 \mathrm{~h}$; $\left.\mathrm{n}\right)$ TFA, $\mathrm{H}_{2} \mathrm{O}, \mathrm{CH}_{2} \mathrm{Cl}_{2}, 23^{\circ} \mathrm{C}, 2 \mathrm{~h}$; o) $\mathrm{NH}_{2} \mathrm{CN}, \mathrm{MeOH}, \mathrm{H}_{2} \mathrm{O}, 50^{\circ} \mathrm{C}, 2 \mathrm{~h}$; p) $\mathrm{TFA}, \mathrm{CH}_{2} \mathrm{Cl}_{2}, 23^{\circ} \mathrm{C}$, $2 \mathrm{~h}$ (42\% over 4 steps). $\mathbf{1 3} \rightarrow \mathbf{1 b}$ : q) $\mathrm{BCl}_{3}, \mathrm{CH}_{2} \mathrm{Cl}_{2}, 0^{\circ} \mathrm{C}, 15 \min (64 \%)$; r) $\mathrm{NH}_{4} \mathrm{OH}, \mathrm{H}_{2}$, $\mathrm{CH}_{3} \mathrm{CN}, 0^{\circ} \mathrm{C}, 2 \mathrm{~h}$ (for chloromethyl iminohydantoin only); then $\mathrm{HCl}, \mathrm{THF}, 45^{\circ} \mathrm{C}, 12 \mathrm{~h}$ $(81 \%)$; s) AD-mix-a, $\mathrm{MeSO}_{2} \mathrm{NH}_{2},{ }^{t} \mathrm{BuOH}-\mathrm{H}_{2} \mathrm{O}, 0^{\circ} \mathrm{C}, 50 \mathrm{~min}\left(55 \%\right.$, d.r.= 2:1-3:1); t) $\mathrm{SmI}_{2}$, 
$\mathrm{H}_{2} \mathrm{O}, \mathrm{THF}, 23^{\circ} \mathrm{C}, 2 \mathrm{~h},(67 \%)$; u) $\mathrm{N}$-bromosuccinimide (NBS), $\mathrm{CH}_{3} \mathrm{CN}, 0^{\circ} \mathrm{C}, 24 \mathrm{~h}(53 \%)$. 13 $\rightarrow$ 16: v) $\mathrm{SmI}_{2}, \mathrm{H}_{2} \mathrm{O}$, THF, $-40 \rightarrow 23^{\circ} \mathrm{C}, 1 \mathrm{~h}(<47 \%)$. 16 $\rightarrow$ 17: w) AD-mix-a, $\mathrm{MeSO}_{2} \mathrm{NH}_{2},{ }^{t} \mathrm{BuOH}-\mathrm{H}_{2} \mathrm{O}, 0^{\circ} \mathrm{C}, 20 \mathrm{~min}(35 \%$, d.r. $>10: 1)$. $\mathrm{BOM}=$ benzyloxymethyl; $\mathrm{Boc}=$ tert-butoxycarbonyl; IBX=2-iodooxybenzoic acid. 